\title{
Mortality of the white pine weevil associated with silvicultural practices in jack pine plantations
}

\author{
by M. Isabel Bellocq and Sandy M. Smith
}

\begin{abstract}
A synthesis of white pine weevil (Pissodes strobi Peck) mortality caused by predation (insects, birds, and mammalian predators), crowding of pupae, and abiotic factors, acting under different stand conditions given by the type of reforestation, depth of the duff, distance from woody debris, and presence of competing vegetation is presented, based on a four-year study conducted in northeastern Ontario. The type of reforestation (planted vs. aerial seeding) did not influence mortality to immature weevils in the leaders from either bird predation, insect predators and parasitoids or crowding of pupae, but $16 \%$ more weevils died during winter in a planted than in a seeded stand suggesting that there was an effect of site condition or small mammal predation on overwintering adults in the duff. Over all conditions, overwintering mortality averaged $76-92 \%$ with small mammal predation representing about $5-13 \%$. Site conditions which augmented small mammal populations and predation, such as proximity to woody debris and presence of competing vegetation, had no effect on overwintering mortality of the weevils. The most important factor influencing overwintering mortality was likely the depth of duff where an inverse relationship was observed between mortality and depth. Forest managers should address conditions of duff depth and small mammal predation to increase the already significant overwintering mortality of adult weevils in young jack pine stands.
\end{abstract}

Key words: Pissodes strobi, silvicultural treatments, planted and seeded stands, competing vegetation, duff layers, small mammal predation, overwintering mortality
Une synthèse sur la mortalité du charançon du pin blanc (Pissodes strobi Peck) provoquée par la prédation (insectes, oiseaux et mammifères prédateurs), l'entassement des chrysalides, et les facteurs abiotiques selon différentes conditions de peuplement en fonction du type de reboisement, de l'épaisseur de la litière, la distance entre les amoncellements de débris ligneux et la présence de végétation concurrente est présentée suite à une étude de quatre ans entreprises dans le nord-est de l'Ontario. Le mode de reboisement (plantation vs ensemencement aérien) n'a eu aucune influence sur la mortalité des charançons immatures présents dans la flèche terminale que se soit par prédation aviaire, insectes prédateurs et parasites ou par l'entassement des chrysalides. Cependant $16 \%$ de charançons de plus moururent au cours de l'hiver dans les plantations par rapport aux peuplements ensemencés laissant entendre qu'il existe un effet selon les conditions de la station ou de la prédation par des petits mammifères sur les adultes passant l'hiver dans la litière. Dans tous les cas, la mortalité hivernale atteignait en moyenne de 76 à $92 \%$, alors que la prédation par les petits mammifères comptait pour 5 à $13 \%$. Les conditions de station qui permettaient d'accroître les populations et la prédation des petits mammifères, comme la proximité de d'amoncellement de débris ligneux et la présence de végétation concurrente, n'ont eu aucun effet sur la mortalité hivernale du charançon. Le plus important facteur influençant la mortalité hivernale semblait être l'épaisseur de la litière puisque qu'une relation inverse entre la mortalité et l'épaisseur a été observée. Les forestiers responsables de l'aménagement devraient porter attention aux conditions entourant l'épaisseur de la litière et la prédation des petits mammifères afin d'accroître la mortalité déjà importante des charançons adultes dans les jeunes peuplements de pin gris.

Mots clés: Pissodes stobi, traitements sylvicoles, plantations et peuplements ensemencés, végétation concurrente, couche d'humus, prédation de petits mammifères, mortalité hivernale

\section{Introduction}

The white pine weevil (Pissodes strobi Peck) has been recognized as a serious pest of white pine (Pinus strobus L.) and sitka spruce (Picea sitchensis (Borg.) Carr.) in North America for more than 60 years, and is now consider a serious concern in jack pine (Pinus banksiana Lamb) plantations in northern Ontario. Jack pine is one of the most common and important tree species in lumber and pulp production in Canada (Morris and Parker 1992). Attack rates by weevils in jack pine of up to $30 \%$ have been reported (Canadian Forest Service 1987) with a potential for up to $13 \%$ reduction in the commercial value of mature stands in northern Ontario (Davidson 1991).

Insect pests can be controlled through a number of pest management options, although these have focused traditionally on the use of chemical and biological insecticides. While effective under certain conditions, these approaches have become increasingly restricted in forestry, leaving the forest manag-

Faculty of Forestry, 33 Willcocks St., University of Toronto, Toronto, Ontario, Canada M5S 3B3. er with few options for pest control. This is the case with the white pine weevil where no biological insecticides are available and only one chemical is currently registered for ground application in Ontario (de Groot 1985).

A significant advance was recently made in the use of IPM for control of the white pine weevil in sitka spruce plantations based on a combination of genetic resistance, chemical control and silvicultural strategies (Alfaro et al. 1994). The silvicultural manipulation of forest stands has often been cited as a long-term solution for controlling forest insects. Unfortunately, silvicultural prescriptions for pest control have been rarely used because little is known about their impact on the biology and ecology of the pest. Although some aspects of the biology of the white pine weevil and its relation with environmental factors or forestry practices were studied in white pine (Sullivan 1961), sitka spruce (Alfaro and Omule 1990), and Norway spruce (Picea abies (L.) Karst.) (Archambault et al. 1993), little was known until recently about the biology and ecology of white pine weevils infesting jack pine plantations. 
A synthesis of mortality factors which affect the white pine weevil in jack pine, based on a four-year study in northeastern Ontario is presented. The study analyzed white pine weevil mortality caused by predation (insects, birds, and mammals), crowding of pupae, and abiotic factors, under different stand conditions given by the type of reforestation (planted and seeded stands), the depth of the duff, distance from woody debris (beside and 100-m from a window of slash), and presence of competing vegetation (weed and weed-free patches).

\section{General Approach}

Weevil mortality caused by either insect predators and parasitoids, crowding of pupae, bird predation, mammalian predation or abiotic factors was quantified in 3-10 year old jack pine plantations infested with weevils. Overwintering mortality of adult weevils in the duff was emphasized because it was the most significant and least understood, particularly in jack pine.

Mortality caused by insect predators and parasitoids and crowding of pupae was examined in planted and seeded stands by placing exclusion cages over weevil-infested leaders, and counting the number of emergence holes in screened (predation excluded) and control (unscreened) leaders. Mortality due to bird predation was quantified by counting the number of pupal chambers excavated by birds and the number of emergence holes in leaders explored by birds and in control leaders (those with no signs of bird predation). Birds were surveyed using the point count technique. Bellocq and Smith (1994b) presented more details on field and statistical methods.

Overwintering mortality was examined under different stand conditions by placing weevils in exclosures that consisted of $20-\mathrm{cm}$ aluminum rings inserted flush with the ground. To quantify mortality caused by mammalian predators (shrews and mice), both control (open) and screened (predation excluded) rings were set up under young jack pines, where weevils overwinter. In the spring, inverted funnels with plastic cups were placed on top of the rings and weevils were collected during emergence from the duff. Abundance of small mammals was estimated under the different stand conditions. A complete description of the field procedure, exclosure design, assessment of overwintering mortality, and small mammal sampling can be found in Bellocq and Smith (1995a).

\section{Silvicultural Aspects \\ Type of Reforestation}

Stand conditions are known to influence attack and development of the white pine weevil in white pine (Sullivan 1961). As with most tree species, the method of reforestation of jack pine affects the density and spatial distribution of trees; trees are more dense and show a stronger clumped pattern in seeded than in planted stands (Bellocq and Smith 1994b). The density and spatial arrangement of trees influence shading and consequently temperature and humidity at the stand and microhabitat levels, and this in turn can affect weevil development and survival. However, the literature shows contrasting results in terms of the influence of overstory shading and stand density on weevil populations. Although shaded stands tend to show lower levels of infestation than exposed plantations in white pine (Stiell and Berry 1985; Wallace and Sullivan 1985), sitka spruce (Alfaro and Omule 1990), and white spruce (Picea glauca (Moench) Voss) (Taylor et al. 1994), higher den-
Table 1. Weevil damage, weevil mortality, and abundance of birds and small mammals in planted and seeded jack pine stands in northeastern Ontario

\begin{tabular}{lcc}
\hline & Planted $(N=\mathbf{5})$ & Seeded $(\boldsymbol{N = 5})$ \\
\hline Duff depth (mm), mean $\pm 1 \mathrm{SE}^{2}$ & $25.3 \pm 1.3$ & $45.2 \pm 2.4$ \\
Mean \% damage by weevils to the stand & 12.0 & 14.0 \\
No. leaders analyzed & 278 & 294 \\
Mean no. pupal chambers/leader & $17.9 \pm 0.8$ & $17.2 \pm 0.8$ \\
Total mortality of pupae (\%) & 55.4 & 56.9 \\
Pupae eaten by birds (\%) & 6.4 & 8.9 \\
Mortality by insects and crowding $(\%)^{1}$ & 32.5 & 56.5 \\
Total no. of bird species 1 & 21 & 23 \\
Mean no. birds detected/150 $\mathrm{m}^{1}$ & 15.1 & 15.4 \\
No. shrews/100 trap nights & 1.5 & 0.5 \\
\hline
\end{tabular}

${ }^{1}$ Conducted in 3 planted and 3 seeded stands

${ }^{2}$ Conducted in 1 planted and 1 seeded stand

sity of white pine weevils was found in seeded than in planted stands of jack pine (Davidson 1991) and attack rates have been independent of tree density in Norway spruce (Archambault et al. 1993).

Weevils killed a similar proportion of leaders in planted and seeded stands of jack pine (Table 1) (Bellocq and Smith 1994b). In addition, the type of reforestation itself does not affect the mortality of immature weevils in the leaders; e.g. predation by birds or insect predators and parasitoids and crowding of pupae in the leaders is similar between the two stand types. Surveys of birds in these young conifer stands suggest that species richness and abundance of birds is not affected by the spatial distribution of trees (Bellocq and Smith 1994b).

Overwintering mortality has been described as a key mortality factor of white pine weevil populations in white pine (Dixon and Houseweart 1982). The overwintering mortality of weevils in jack pine stands is also significant and can be influenced by tree spacing (Fig. 1a) (Bellocq and Smith 1994b). In the adult stage of the weevil, there was significantly higher mortality in a planted than in a seeded stand. The higher mortality was associated with a relatively higher abundance of shrews (Table 1).

\section{Depth of Duff}

The white pine weevil overwinters as an adult between the upper zone of dry needles and the lower zone of moist organic debris, about $20 \mathrm{~cm}$ from the bole of host trees (Dixon et al. 1979). High moisture content of overwintering sites may cause insect mortality through the formation of ice crystals (Danks 1978), and the duff depth may influence this mortality in that a shallower duff could lead to higher mortality (Bellocq and Smith 1994b).

Adult weevils were placed in rings ( 10 weevils/ring) and it was found that weevil survival decreased with decreasing depths of duff (Fig. 1b) (Bellocq and Smith 1995a). Similarly, overwintering mortality of adult weevils is considerably lower in white pine (29-50\%) (Dixon and Houseweart 1982) than in jack pine stands which is consistent with a higher duff layer in white pine $(6.8 \mathrm{~cm})$ than in jack pine $(2.5-4.5 \mathrm{~cm})$ (Table 1 ). This suggests that the amount of duff under host trees may be a major factor determining the overwintering survival of adult weevils.

Our experiment used only screened rings (where mammalian predation was excluded) to examine abiotic factors, and thus, we do not know what the additional impact of small mammal 


\section{a - Reforestation technique}

OоTHER FACTORS $\square$ MAMMMALAN PAEDATION

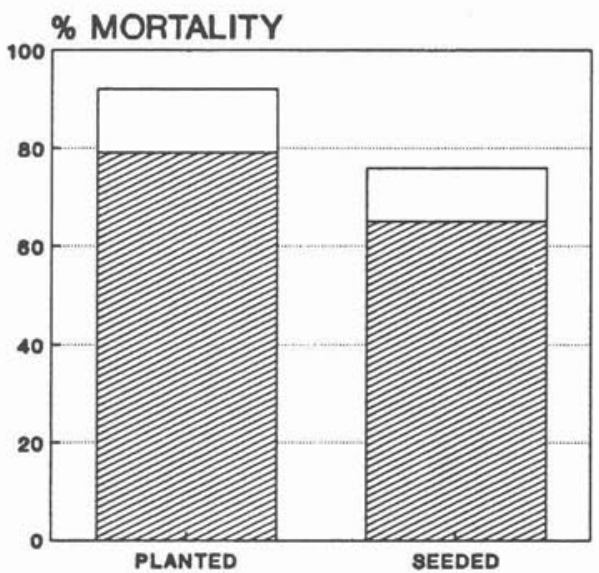

PLANTED

\section{b - Depth of duff}

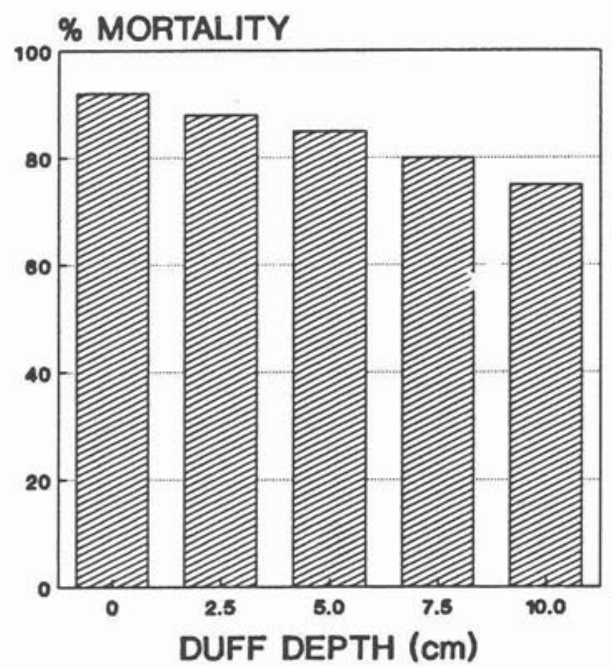

d - Competing vegetation

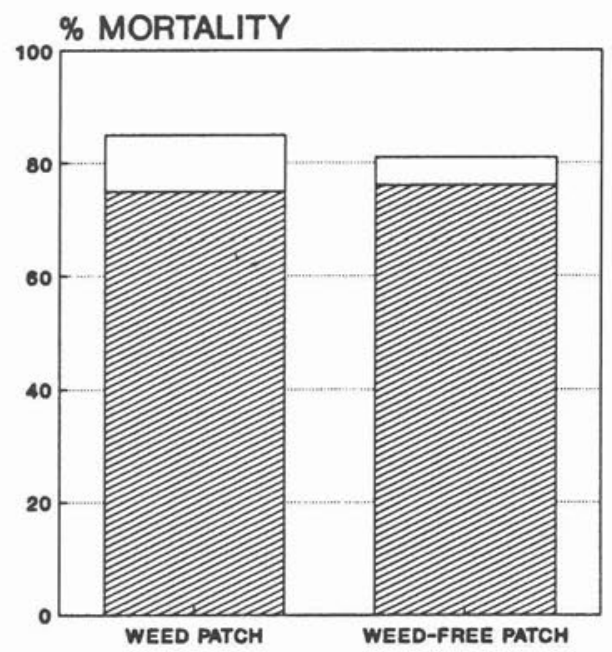

Fig. 1. Percentage overwintering mortality of the white pine weevils under different stand conditions given by (a) the type of reforestation, (b) depth of duff, (c) distance from woody debris, and (d) presence of competing vegetation in jack pine plantations in northeastern Ontario.

predation may have been at different depths. We can assume that shrews and deer mice (Peromyscus maniculatus) would be predators in this system because: 1) they are active during winter; 2) both the masked shrew (Sorex cinereus) and the deer mouse accept adult weevils as a food item, albeit a non-preferred one (Bellocq and Smith 1994a); 3) most species of shrews and mice have been shown to forage effectively within the upper duff layers (Semel and Andersen 1988; Churchfield 1980; Holling 1958). In addition, adult weevils would be easily accessible to small mammals in these young jack pine stands because the duff layer rarely exceeds $4.5 \mathrm{~cm}$ (Table 1) and Dixon et al. (1979) showed that adult weevils do not overwinter below $3.5 \mathrm{~cm}$. Our data, however, suggest that small mammal predation is inde- pendent of the depth of duff $(13 \%$ when the duff averaged 2.5 $\mathrm{cm}$ in the planted stand and $11 \%$ when the duff averaged 4.5 $\mathrm{cm}$ in the seeded stand) (Table 1 and Fig. 1a) (Bellocq and Smith 1995a).

\section{Amount of Woody Debris}

The extent and arrangement of woody debris on a site after harvesting and during early stand regeneration also has implications for the survival of weevils, particularly during the winter. The amount of woody debris present is an important component in the management of wildlife (Maser et al. 1979). Some species of rodents (including predators of weevils) increase their abundance when woody debris (slash, stumps, 
and logs piled in rows) is present (Larson et al. 1986). Furthermore, debris influences the microclimate (e.g. temperature, humidity, wind velocity, drainage) of sites in the soil where weevils overwinter and this may affect their survival (Sullivan 1961; Dixon and Houseweart 1982).

The mortality of white pine weevils overwintering either beside or $100 \mathrm{~m}$ away from a slash windrow was quantified, and it was found that this had no effect on their survival (Fig. 1c) (Bellocq and Smith 1995a). Although mammalian predation was a significant mortality factor overall and the abundance of deer mice was higher beside debris ( 2.2 individuals $/ 100$ trap nights) than $100 \mathrm{~m}$ away ( 0.9 individuals/100 trap nights), this appeared to have no influence on the survival of weevils in soil, possibly because mice and not shrews were caught beside the woody debris. Deer mice may be less important predators of overwintering weevils than shrews because they are omnivore rather than insectivore and have a lower metabolic rate than shrews.

\section{Presence of Competing Vegetation}

The presence of competing vegetation may also influence weevil survival through shading that affects weevil establishment and success while developing in the leaders, and through indirect effects on the density of small mammals foraging on adult weevils. As discussed above, overstory shading affects weevil attack and damage to stands depending on the tree species involved. Herbicide applications reduce vegetation cover and structure, and this in turn may influence the abundance of certain insectivorous mammals (Santillo et al. 1989). For example, previous work on microhabitat selection by the masked shrew showed that shrews avoid travelling in open areas of young jack pine (Bellocq and Smith 1995b). This suggests that stands where competing vegetation was controlled early in the regeneration phase may be less suitable for shrew populations and may result in reduced predation by shrews on overwintering weevils.

Damage by weevils (percentage of leaders killed by weevils in a stand), overwintering mortality, plant biomass, and abundance of small mammals were measured in a weed and weed-free patch of a weevil-infested four-year old jack pine plantation. Although plant biomass was higher in the weed (672.4 $\left.\pm 93.2 \mathrm{~g} \mathrm{~m}^{-2}\right)$ than in the weed-free $\left(263.3 \pm 80.1 \mathrm{~g} / \mathrm{cm}^{-2}\right)$ patch, damage by weevils was similar in both patches (weed = $6.5 \%$ and weed-free $=9.3 \%$ ). Mammalian predation was significant in the weed patch where more small mammals were caught compared to that in the weed-free patch; however, winter mortality of the weevil was not affected by the presence of competing vegetation (Fig. 1d) (Bellocq and Smith 1995a).

\section{Management Implications}

Adult weevils that successfully emerge from overwintering sites in the spring hold the highest reproductive value. This makes them a desirable target for control prescriptions. Our studies show that a large percentage (76-92\%) of adult white pine weevils die each year while overwintering in young jack pine stands. The main causes of this mortality appear to be: 1) abiotic factors which may be associated with the depth of the duff layer, and 2) mammalian predation. Both of these factors can be influenced by the forest manager through silvicultural manipulation.
We found that mortality of weevils increased with decreasing depths of duff. Dispersal of weevils is limited during the fall (Dixon et al. 1979), and weevil attack and damage to leaders in a stand tend to be clumped. Consequently, removing leaf litter under trees damaged by weevils and the surrounding trees in the fall may result in increased mortality of adult weevils during the winter.

Small mammal predation was responsible for $5-13 \%$ mortality of overwintering adult weevils. Thus, prescriptions to increase habitat heterogeneity would promote higher populations of small mammals; for instance, leaving woody debris in the stand after harvesting (e.g. tree length logging as opposed to whole tree) or encouraging understory cover (e.g. avoiding herbicide applications).

Increasing overwintering mortality of weevils may have a major effect on the next generation. Our results suggest that approximately $7.6 \%$ of the weevil population in tree leaders will survive to become overwintering adults in a seeded stand (Bellocq and Smith 1995b). Hypothetically, if we could increase the predation rate by mammals (or mortality by abiotic factors) to $21-23 \%$ over the winter (up by $10 \%$ ), then the population of adult weevils emerging the following spring should be reduced to $4.1 \%$ (given that no density-dependent factors are operating). From a management perspective, it remains to determine whether such reductions would lead to corresponding reductions in damage.

\section{Acknowledgments}

We thank A. Applejohn, A. Breau, C. Dasabrais, K. Fernie, P. Henriquez, J. Lukianchuk, and N. Maheswaren for their research assistance. $C$. Sanders provided valuable suggestions for improving the manuscript. This work could not have been completed without the logistical support of E.B.Eddy Forest Products Inc. Funding from the Canadian Forest Service's Green Plan, the Canada-Ontario Forest Research Development Agreement, and the Northern Ontario Development Agreement is also gratefully acknowledged.

\section{References}

Alfaro, R.I., J.H. Borden, R.G. Fraser and A. Yanchuk. 1994. An integrate pest management system for the white pine weevil. In: The white pine weevil: biology, damage and management. R.I. Alfaro, G. Kiss and G. Fraser (Eds.). Forest Resource Development, Report No. 226: 226-238.

Alfaro, R.I. and S.A.Y. Omule. 1990. The effect of spacing on spruce weevil damage to sitka spruce. Can. J. For. Res. 20: 179-184.

Archambault, L., J. Morissette, R. Lavallée and B. Comtois. 1993. Susceptibility of Norway spruce plantations to white pine weevil attacks in southern Quebec. Can. J. For. Res. 23: 2362-2369.

Bellocq, M.I. and S.M. Smith. 1994a. Arthropods preferred as food by Sorex cinereus (masked shrew) and Peromyscus maniculatus (deer mouse): an experimental approach. Mammalia 58: 391-396.

Bellocq, M.I. and S.M. Smith. 1994b. Predation and overwintering mortality of Pissodes strobi, the white pine weevil, in planted and seeded jack pine. Can. J. For. Res. 24: 1426-1433.

Bellocq, M.I. and S.M. Smith. 1995a. Influence of reforestation technique, slash, competing vegetation, and duff depth on the overwintering mortality of Pissodes strobi (Coleoptera: Curculionidae), the white pine weevil. For. Ecol. Manage. 78: 1-10.

Bellocq, M.I. and S.M. Smith. 1995b. Manejo de Pissodes strobi (Coleoptera, Curculionidae) en bosques de Pinus banksiana en Ontario, Canadá: mortalidad por predación y selección de microhabitat por mamíferos predadores. Ecología Austral 5: 11-20. 
Canadian Forest Service. 1987. Forest insects and disease survey. Canadian Forest Service Great Lakes Forestry Centre Sault Ste. Marie, ON. Survey Bulletin.

Churchfield, S. 1980. Subterranean foraging and burrowing activity of the common shrew. Acta Theriolog. 25: 451-459.

Danks, H.V. 1978. Models of seasonal adaptation in the insects. I. Winter survival. Can. Entomol. 110: 1167-1205.

Davidson, B.S. 1991. Impact of terminal stem loss on mature jack pine and its relationship to managing the white pine weevil in young jack pine plantations. M.Sc. Thesis, University of Toronto, Tooronto, ON. 102 p.

De Groot, P. 1985. Chemical control of insect pests of white pine. Proc. Entomol. Soc. Ont. 116 (Suppl.): 67-71.

Dixon, W.N. and M.W. Houseweart. 1982. Life tables of the white pine weevil in central Maine. Environ. Entomol. 11: 555-564. Dixon, W.N., M.W. Houseweart and S.M. Sheffer. 1979. Fall temporal activity and overwintering sites of the white pine weevil, Pissodes strobi, in Central Maine. Ann. Entomol. Soc. Am. 2: 840-844.

Holling, C.S. 1958. Sensory stimuli involved in the location and selection of sawfly cocoons by small mammals. Can. J. Zool. 36: 633-653. Larson, F.R., P.F. Folliott and P. Warren. 1986. Managing wildlife habitat. In southern ponderosa pine forests, diverse treatments are the key. J. For. 3: 40-41.

Maser, C., R.G. Anderson, K. Cromack, Jr., J.T. Williams and R.E. Martin. 1979. Dead and down woody material. In: Wildlife habitats in managed forests: the Blue Mountains of Oregon and Washington. J.W. Thomas (Ed.). U.S. For. Serv. Agric. Handb. pp. 78-95.
Morris, D.M. and W.H. Parker. 1992. Variable-quality form in mature jack pine stands: quantification and relationship with environmental factors. Can. J. For. Res. 22: 279-289.

Santillo, D.J., D.M. Leslie Jr. and P.W. Brown. 1989. Responses of small mammals and habitat to glyphosate application on clearcuts. J. Wildl. Manage. 53: 164-172.

Semel, B. and D.C. Andersen. 1988. Vulnerability of acorn weevils (Coleoptera: Curculionidae) an attractiveness of weevils and infested Quercus alba acorns to Peromyscus leucopus and Blarina brevicauda. Am. Midl. Nat. 119: 385-393.

Stiell, W.M. and A.B. Berry. 1985. Limiting white pine weevil attacks by side shade. For. Chron. 61: 5-9.

Sullivan, C.R. 1961. The effect of weather and the physical attributes of white pine leaders on the behaviour and survival of the white pine weevil, Pissodes strobi Peck, in mixed stands. Can. Entomol. 93: 721-741.

Taylor, S.P., R. Alfaro, C. Delong, and L. Rankin. 1994. The effects of overstory shading on white pine weevil damage to interior white spruce. In: The white pine weevil: biology, damage and management. R.I. Alfaro, G. Kiss and G. Fraser (Eds.). Forest Resource Development, Report No. 226: 254-261

Wallace, D.R. and C.R. Sullivan. 1985. The white pine weevil, Pissodes strobi (Coleoptera: Curculionidae): a review emphasizing behaviour and development in relation to physical factors. Proc. Entomol. Soc. Ont. 16 (Suppl.): 39-62. 